\title{
The Effect of Module Implementation with STAD Cooperative Learning Toward Process Skills in Science and Cognitive Achievement of 8th Grade Students
}

\author{
Yayuk Prihatnawati \\ SMP Laboratorium Universitas Negeri Malang \\ Malang, Indonesia \\ yayuk_amin@yahoo.co.id
}

\author{
Mohamad Amin, Mimien Henie Irawati Al Muhdhar \\ Jurusan Biologi FMIPA Universitas Negeri Malang \\ Malang, Indonesia \\ mohamad.amin.fmipa@um.aca.id
}

\begin{abstract}
Teaching and learning using module as a teaching materials at Laboratory Junior High School Universitas Negeri Malang conducted individually and in groups gives heterogeneous cognitive learning outcomes. The one of solution that can be used to overcome these problems is implement the module based on cooperative learning of STAD as an effort to improve the quality of learning. Improving the quality of learning is expected to have an impact on the increase of students' cognitive learning achievement. The purpose of this research is to explain the influence of the implementation of teaching materials module with STAD cooperative learning on: (1) science process skill, and (2) student cognitive learning result on material Plant life system in VIII grade Laboratory Junior High School Universitas Negeri Malang. This research is a quasi-experimental research with Pretest Posttest Non-equivalent Control Group Design. The results showed that the implementation of teaching materials module with STAD cooperative learning has a significant effect on the science process skill and cognitive learning outcomes of students of VIII Laboratory Junior High School Universitas Negeri Malang. The research results show that mean scores corrected (mean) science process skills $10.41 \%$ and cognitive learning achievement $4.2 \%$ higher in the class who learn to use modules with STAD cooperative learning. In general, the implementation of module learning with STAD cooperative learning can improve the science process skills, and cognitive learning achievement.
\end{abstract}

Keywords-module, STAD, cognitive achievement

\section{INTRODUCTION}

Education is closely related to the learning process. Learning process is basically a communication process that is realized through the delivery of information to the students. Information presented generally in the form of knowledge, skills, skills, ideas, experience, and so forth. Such information is usually packed as a whole that is teaching materials [1]. Teaching material is a set of subject matter organized systematically, displaying the whole figure of the competencies that will be mastered students in learning activities. The existence of teaching materials provides an opportunity for students to master a standard of competence or basic competence in a coherent and systematic that is accumulatively able to master the overall competence as a whole and integrated.

Module is one of the teaching materials used as a systematically learning tool that contains material, methods, limitations, and how to evaluate and interesting to achieve the expected competence in accordance with the level of complexity. Module is one of the teaching materials used as a learning tool that contains material, methods, limitations, and how to evaluate systematically designed and interesting to achieve the expected competence in accordance with the level of complexity. Teaching learning by using module as a teaching materials has an advantage which can improve the quality of learning. Some of the advantages of modules include: (1) self-instructional, which means through the module students are able to learn themselves; (2) selfcontained, which means the module contains all learning materials from a number of competency units studied; (3) stand alone, which means the module does not depend on other media; (4) adaptive, which means the module adapts to the development of science and technology and is flexible to use for a certain period of time; and (5) user friendly, which means the module contains instructions and exposure of information that appears to be helpful and easy with the user, including user ease in responding and accessing the students wishes [2]. In addition to the advantages, the module also has weaknesses, among others: (1) self-study for some students is difficult, (2) self-study tends to make students individual character.

One example of cooperative learning is STAD that can increase student participation, facilitate students with experience of leadership attitude, make decisions in group and give opportunity to students of different background, all of which is expected to learn each other among student [3] Students who have mastered procedural steps in their group can help all students in their group in developing the science process

skills. The disadvantages of using individual module teaching 
materials will make students individual, uncooperative, unconcerned and less able to appreciate diversity. The use of module teaching materials with STAD cooperative learning is expected to reduce these matters, and in turn improve better learning outcomes through mastery learning, with the value of cooperative character and respect for diversity in achieving competence (Prihatnawati, 2013). Implementation of modules with STAD cooperative learning is expected to develop the science process skills and students' cognitive learning outcomes. The use of module teaching materials with STAD cooperative learning is expected to improve better learning achievement.

\section{METHODS}

This research is a quasi-experiment research with PretestPosttest Non Equivalent Control Group Design. This study, using two groups of samples, given different treatment of learning by implementing module teaching materials without STAD cooperative learning and learning by implementing module teaching materials with STAD cooperative learning. The treatment aims to detect the effect of treatment on the science process skill and the students' cognitive learning achievement. The population in this research is all students of 8nd Grade Junior High School Laboratory State University of Malang in regular program of the academic year 2012/2013 which totally 138 students. Determination of sample through purposive sampling technique. Research instruments in this research are: (1) complete module as teaching materials and its evaluation; (2) learning instruction include syllabus and lesson plan; (3) a description test for obtaining data on science process skills and cognitive learning achievement; and (4) observation sheets for the implementation of lesson plan syntax.

Testing the items done before the experimental research to determine the validity of the item and the reliability of test instruments that will be used. Validity of test performed is the validity of the item is calculated by calculating the correlation with Product Moments correlation formula from Pearson [4] with the following formula:

$$
\begin{aligned}
& \mathrm{r}_{\mathrm{xy}}=\frac{N \sum x y-\left(\sum x\right)\left(\sum y\right)}{\sqrt{\left\{N \sum x^{2}-\left(\sum x\right)^{2}\right\}\left\{N \sum y^{2}-\left(\sum y\right)^{2}\right\}}} \\
& \mathrm{r}_{\mathrm{xy}}=\text { correlation coefficient between variables } \mathrm{x} \text { and } \mathrm{y} \\
& \mathrm{N} \quad=\text { number of samples }
\end{aligned}
$$

When the $r_{x y}$ value $<r$ table, then the correlation is not significant so the question item is called to be unvalid. And vice versa, when $r_{x y}>r$ table then the question item declared valid. Validity analysis is assisted with Microsoft Excel 2007 for Windows.

Reliability test is done through coefficient of reliability with Alpha Cronbach formula. Calculations performed with software program Microsoft Excel 2007 for Windows, with the following formula:

$$
\begin{aligned}
& \mathrm{R}_{1}=\frac{K}{K-1}\left\{1-\frac{\Sigma s t^{2}}{S t^{2}}\right\} \\
& \mathrm{R} 1=\text { instrument reliability } \\
& \mathrm{K} \quad=\text { the mean of squares between subjects } \\
& \Sigma \mathrm{St} 2=\text { average squared error } \\
& \mathrm{St} 2=\text { total variance }
\end{aligned}
$$

Criteria of reliability tests by [4] as follows:

0.80 - 1.00: very high

$0.60-0.79$ : high

0.40 - 0.59: enough

0.20 - 0.39: Low

$0.00-0.19$ : very low

The data of the research were analyzed using descriptive and inferential statistics. Descriptive analysis in the form of mean value and standard deviation to describe score of science skills process and cognitive learning achievement. Inferential statistical analysis to test the hypothesis of the influence of the implementation of module as teaching materials with STAD cooperative learning to science process skills and cognitive learning achievement using covariance analysis, while the effect of implementation on the development of student character using variance analysis. Statistical analysis assisted with SPSS 16.0 for Windows, performed at $5 \%$ significance level.

\section{RESULT}

\section{A. Data description}

1) Data description of science process skills

The data of science process skill obtained from the following aspects: make observations, develop hypotheses, plan experiments, collect data and also conclusions. A summary of science process skill data can be presented in Table 1 .

The results showed that the teaching and learning in science subject that implements module as teaching materials with STAD cooperative learning has a significant effect on science skill process score. The score average of science process skill in the class that implements the module with STAD cooperative learning has a mean score of $10.41 \%$ higher than the class that implements the module without cooperative learning STAD

TABLE I. Score Average of Pretest And Postest of ScIENCE PROCESS SKILLS

\begin{tabular}{|l|l|l|l|l|l|}
\hline \multirow{2}{*}{ No } & \multirow{2}{*}{ Aspect KPS } & \multicolumn{2}{c|}{ Control class } & \multicolumn{2}{c|}{ Experiment class } \\
\cline { 3 - 6 } & & Pretest & Posttest & Pretest & Posttest \\
\hline 1 & Observing & 0.25 & 3.15 & 0.28 & 3.40 \\
\hline 2 & Preparing the hypothesis & 0.50 & 2.5 & 0.38 & 2.53 \\
\hline 3 & Conducting experiment & 0.94 & 3.43 & 1.13 & 3.86 \\
\hline 4 & Collecting data & 0.80 & 2.08 & 0.75 & 2.13 \\
\hline 5 & Formulation conclusions & 0.20 & 2.33 & 0.25 & 2.83 \\
\hline
\end{tabular}




\section{2) Data Description of Cognitive Achievement}

The Cognitive Achievement is the ability that the students obtained after implementing the learning process. The achievement measured include six domains: remembering $(\mathrm{C} 1)$, understanding (C2), applying (C3), analyzing (C4), assessing (C5), and creating (C6). The summary of pretest and posttest score presented in Table 2.

TABLE II. Score AVERAge of Pretest ANd Postest of Cognitive ACHIEVEMENT

\begin{tabular}{|l|l|l|l|l|l|}
\hline \multirow{2}{*}{ No } & \multirow{2}{*}{ Domain } & \multicolumn{2}{c|}{ Control class } & \multicolumn{2}{c|}{ Experiment class } \\
\cline { 3 - 6 } & & Pretest & Postest & Pretest & Postest \\
\hline 1. & remembering (C1) & 2.85 & 3.30 & 2.28 & 3.05 \\
\hline 2. & understanding (C2) & 1.63 & 2.53 & 1.55 & 2.75 \\
\hline 3. & applying (C3) & 0.78 & 2.80 & 0.90 & 3.10 \\
\hline 4. & analyzing (C4) & 1.58 & 2.65 & 1.61 & 2.91 \\
\hline 5. & assessing (C5) & 2.30 & 2.86 & 2.36 & 2.91 \\
\hline 6. & creating (C6) & 0.70 & 1.55 & 0.70 & 1.63 \\
\hline
\end{tabular}

TABLE III. RESULT OF DATA NORMALITY TEST OF SCIENCE PROCESS SKILLS

\begin{tabular}{|l|l|l|l|}
\hline $\begin{array}{c}\text { Group of } \\
\text { data }\end{array}$ & \multicolumn{1}{|c|}{ Teaching and learning } & \multicolumn{1}{|c|}{$\begin{array}{c}\text { Sig (2- } \\
\text { tailed) }\end{array}$} & \multicolumn{1}{c|}{$\begin{array}{c}\text { Data } \\
\text { Distribution }\end{array}$} \\
\hline Pretest & $\begin{array}{l}\text { Implementation module } \\
\text { without STAD }\end{array}$ & 0,086 & Normal \\
\cline { 2 - 4 } & $\begin{array}{l}\text { Implementasi module with } \\
\text { STAD }\end{array}$ & 0,169 & Normal \\
\hline Postest & $\begin{array}{l}\text { Implementasi module } \\
\text { without STAD } 0,641\end{array}$ & Normal \\
\cline { 2 - 4 } & $\begin{array}{l}\text { Implementasi module with } \\
\text { STAD }\end{array}$ & 0,075 & Normal \\
\hline
\end{tabular}

TABLE IV. THE RESULTS OF DATA HOMOGENEITY TEST OF SCIENCE PROCESS

\begin{tabular}{|l|l|l|l|}
\hline Levene Statistic & df1 & df2 & Sig. \\
\hline 6.381 & 1 & 78 & .231 \\
\hline
\end{tabular}

TABLE V. RESULT OF DATA NORMALITY TEST OF COGNITIVE ACHIEVEMENT.

\begin{tabular}{|l|l|l|l|}
\hline $\begin{array}{c}\text { Group of } \\
\text { data }\end{array}$ & \multicolumn{1}{|c|}{ Teaching and learning } & \multicolumn{1}{|c|}{$\begin{array}{c}\text { Sig (2- } \\
\text { tailed) }\end{array}$} & $\begin{array}{c}\text { Data } \\
\text { distribution }\end{array}$ \\
\hline Pretest & $\begin{array}{l}\text { Implementation module } \\
\text { without } S T A D\end{array}$ & 0,448 & Normal \\
\cline { 2 - 4 } & $\begin{array}{l}\text { Implementasi module with } \\
\text { STAD }\end{array}$ & 0,995 & Normal \\
\hline Postest & $\begin{array}{l}\text { Implementasi module } \\
\text { without STAD }\end{array}$ & 0,513 & Normal \\
\cline { 2 - 4 } & $\begin{array}{l}\text { Implementasi module with } \\
\text { STAD }\end{array}$ & 0,230 & Normal \\
\hline
\end{tabular}

TABLE VI. THE RESULTS OF DATA HOMOGENEITY TEST OF COGNITIVE ACHIEVEMENT

\begin{tabular}{|l|l|l|l|}
\hline Levene Statistic & df1 & df2 & Sig. \\
\hline 4.446 & 1 & 78 & .368 \\
\hline
\end{tabular}

The research data shows that students who learn use module as a teaching material with STAD cooperative learning have increased the mean score higher than students use module without STAD cooperative learning. All aspects from remembering (C1) until creating (C6) show an increasing tendency Table 2.

\section{B. Data Normality and Homogeneity Test}

The assumption test includes normality test and homogeneity of variance were conducted before covariance analysis Anakova.

1) Data Normality and Homogeneity Test of science process skills.

Table 3 shows a summary of the results of normality test of science process skills

Table 3 shows that based on the normality test obtained sig (p-level) in all data groups (pretest and posttest), both in the learning group by implementing module without cooperative learning STAD as well as the learning that implementing module with cooperative learning STAD shows that result greater than 0.05 ( $p>0.05)$. This means Ho is accepted, the data comes from a normal distribution. The results of data homogeneity test of science process skill are summarized in Table 4.

Table 4 shows that data homogeneity test of science process skill obtained sig (p-level) values greater than 0.05 ( $p>0.05$ ). This shows that Ho is accepted, which means that the variants between groups of data are not different or homogeneous. The result of data normalityty test of science process skill is normal distribution and from homogeneity test indicate that variance between groups is homogeneous data, so that data of science process skill is qualified for parametric test through anakova test.

2) Data Normality and Homogeneity Test of cognitive achievement.

Table 5 shows a summary of the results of data normality test of cognitive achievement

Table 5 shows that based on the normality test obtained sig (p-level) in all data groups (pretest and posttest), both in the learning group by implementing module without cooperative learning STAD as well as the learning that implementing module with cooperative learning STAD shows that result greater than $0.05(\mathrm{p}>0.05)$. This means Ho is accepted, the data comes from a normal distribution. The results of data homogeneity test of science process skill are summarized in Table 4.

Table 4 shows that data homogeneity test of cognitive achievement obtained sig ( $\mathrm{p}$-level) values greater than 0.05 ( $p>0.05$ ). This shows that Ho is accepted, which means that the variants between groups of data are not different or homogeneous. The result of data normalityty test of cognitive achievement is normal distribution and from homogeneity test indicate that variance between groups is homogeneous data, so that data of cognitive achievement is qualified for parametric test through anakova test. 


\section{Hypothesis testing}

The effect of module implementation as teaching material combined with Student Team Achievement Division (STAD) cooperative learning toward process skills in science.

A summary of the results of the anakova test on the dependent variables of science process skills is presented in Table 7.

Table 7 shows that in the learning strategy source obtained p-level value is smaller than alpha $0,05(\mathrm{p}<0,05)$ with sig value equal to 0,005 . These results indicate that the hypothesis of research which states that there is influence of the implementation of module as teaching materials with cooperative learning (STAD) on the science process skills of students $8^{\text {nd }}$ Grade Junior High School Laboratory State University of Malang is accepted. The results of the anakova test were continued in the advanced test with Least Significant Difference (LSD) test. A summary of further test results on the effect of treatment on science skill process is presented in Table 8 .

Table 8 shows that the mean score of science process skill in the group that implements the module with cooperative learning STAD is higher than the group that implements the module without cooperative learning STAD. When expressed in percent, the score of science process skill in the group that implements the module with cooperative learning STAD has a mean score of $10.41 \%$ higher than the one that implements the module without cooperative learning STAD.

The effect of module implementation as teaching material combined with Student Team Achievement Division (STAD) cooperative learning toward cognitive achievement. A summary of the results of the anakova test on the dependent variables of cognitive achievement is presented in Table 9.

Table 9 shows that in the learning strategy source obtained p-level value is smaller than alpha $0,05(\mathrm{p}<0,05)$ with sig value equal to 0,005 . These results indicate that the hypothesis of research which states that there is influence of the implementation of module as teaching materials with cooperative learning (STAD) on the cognitive achievement of students $8^{\text {nd }}$ Grade Junior High School Laboratory State University of Malang is accepted. The results of the anakova test were continued in the advanced test with Least Significant Difference (LSD) test. A summary of further test results on the effect of treatment on cognitive achievement is presented in Table 10.

Table 10 shows that the mean score of cognitive achievement in the group that implements the module with cooperative learning STAD is higher than the group that implements the module without cooperative learning STAD. When expressed in percent, the score of student cognitive achievement in the group that implements the module with cooperative learning STAD has a mean score of $4.2 \%$ higher than the one that implements the module without cooperative learning STAD.
TABLE VII. SUMMARY OF ANAKOVA TEST OF STUDENT SCIENCE PROCESS SKILL

\begin{tabular}{|l|l|l|l|l|l|}
\hline \multicolumn{1}{|c|}{ Source } & $\begin{array}{c}\text { Type III Sum of } \\
\text { Squares }\end{array}$ & df & $\begin{array}{c}\text { Mean } \\
\text { Square }\end{array}$ & F & Sig. \\
\hline $\begin{array}{l}\text { Corrected } \\
\text { Model }\end{array}$ & $1060,239^{\mathrm{a}}$ & 2 & 530,119 & 4,315 &, 017 \\
\hline Intercept & 17635,785 & 1 & 17635,785 & 143,537 &, 000 \\
\hline Pretest_KPS & 101,126 & 1 & 101,126 &, 823 & .367 \\
\hline Strategi & 1040,014 & 1 & 1040,014 & 8,465 & .005 \\
\hline Error & 9460,649 & 77 & 122,866 & & \\
\hline Total & 448157,000 & 80 & & & \\
\hline $\begin{array}{l}\text { Corrected } \\
\text { Total }\end{array}$ & 10520,887 & 79 & & & \\
\hline
\end{tabular}

TABLE VIII. A SUMMARY OF FURTHER TEST RESULTS ON THE EFFECT OF TREATMENT ON SCIENCE SKILL PROCESS

\begin{tabular}{|l|l|l|l|l|l|}
\hline $\begin{array}{c}\text { Teaching } \\
\text { and } \\
\text { learning }\end{array}$ & Pretest & Postest & Difference & $\begin{array}{c}\text { Corrected } \\
\text { score } \\
\text { average }\end{array}$ & $\begin{array}{c}\text { LSD } \\
\text { Notation }\end{array}$ \\
\hline $\begin{array}{l}\text { Module } \\
\text { without } \\
\text { STAD }\end{array}$ & 15,10 & 70,42 & 55,32 & 70,301 & $\mathrm{a}$ \\
\hline $\begin{array}{l}\text { Modul + } \\
\text { STAD }\end{array}$ & 16,25 & 77,40 & 61,15 & 77,624 & $\mathrm{~b}$ \\
\hline
\end{tabular}

TABLE IX. SUMMARY OF ANAKOVA TEST OF STUDENT COGNITIVE ACHIEVEMENT

\begin{tabular}{|l|l|l|l|l|c|}
\hline \multicolumn{1}{|c|}{ Source } & $\begin{array}{c}\text { Type III Sum of } \\
\text { Squares }\end{array}$ & df & $\begin{array}{c}\text { Mean } \\
\text { Square }\end{array}$ & F & Sig. \\
\hline $\begin{array}{l}\text { Corrected } \\
\text { Model }\end{array}$ & $469,232^{\mathrm{a}}$ & 2 & 234,616 & 2,603 &, 081 \\
\hline Intercept & 17952,781 & 1 & 17952,781 & 199,167 &, 000 \\
\hline $\begin{array}{l}\text { Pretest } \\
\text { Kognitif }\end{array}$ & 301,032 & 1 & 301,032 & 3,340 &, 072 \\
\hline Strategi & 191,882 & 1 & 191,882 & 2,129 &, 015 \\
\hline Error & 6940,718 & 77 & 90,139 & & \\
\hline Total & 3744,000 & 80 & & & \\
\hline $\begin{array}{l}\text { Corrected } \\
\text { Total }\end{array}$ & 7409,950 & 79 & & & \\
\hline
\end{tabular}

TABLE X. SUMMARY OF FURTHER TEST RESULTS ON THE EFFECT OF TREATMENT ON COGNITIVE ACHIEVEMENT

\begin{tabular}{|l|l|l|l|l|c|}
\hline $\begin{array}{c}\text { Teaching } \\
\text { and } \\
\text { learning }\end{array}$ & Pretest & Postest & Difference & $\begin{array}{c}\text { Corrected } \\
\text { score } \\
\text { average }\end{array}$ & $\begin{array}{c}\text { LSD } \\
\text { Notation }\end{array}$ \\
\hline $\begin{array}{l}\text { Module } \\
\text { without } \\
S T A D\end{array}$ & 43 & 66,25 & 23,25 & 73,700 & $\mathrm{a}$ \\
\hline $\begin{array}{l}\text { Modul + } \\
\text { STAD }\end{array}$ & 41,48 & 69,06 & 27.58 & 76,625 & $\mathrm{~b}$ \\
\hline
\end{tabular}




\section{DISCUSSION}

A. The effect of module implementation as teaching material combined with Student Team Achievement Division (STAD) cooperative learning toward science process skills in Life System in Plants for 8nd Grade Junior High School Laboratory State University of Malang.

The results of this study indicate that the learning of science that implement module as teaching materials with cooperative learning STAD have a significant effect on science skill process score. Students who learn use module with cooperative learning STAD have a higher average score or increase that compared to students who learn by using module but without cooperative learning STAD. Improvement of science process skill can be seen from the increase of science score of pre-test and posttest of science process skill. When viewed from the mean corrected mean, the students studying with cooperative learning STAD have higher scores of science process skills than the groupe use the module without cooperative learning STAD. Further test show that the implementation of module as teaching materials with cooperative learning STAD has a significant effect on the science process skill. Further test also indicate that there are differences in the ability of science process skills between students whot learn use modules with cooperative learning STAD and group of students who learn use modules without cooperative learning STAD. The score average of science process skill in the group that implements the module with cooperative learning STAD has mean score of corrected (mean) $10.41 \%$ higher when compared with the class that implements the module without cooperative learning STAD. This result is supported by [5] which concluded that cooperative learning STAD has an effect on students' science process skill in biology teaching and learning process in SMA in Metro Lampung. The difference of research result with new findings in this research is the implementation of module as an instructional material which is learned by cooperative learning STAD has significant influence to the science process skill of students Junior High School Laboratory State University of Malang.

The results of this study also indicate that the implementation of modules with cooperative learning STAD can give a positive influence on students' science process skills. This can be seen in every aspect of IPA process skill in groups of students using modules with STAD cooperative learning there is an increase score.

The increase of skill score of observation is caused by cooperative learning STAD which emphasizes student activity in groups so that students can develop the ability to observe together [6]. Individual responsibility in the group can improve the maximum group work results and also motivate other students to make a good observation as well. By conducting good observation activities, Abruscato [7] can provide clear guidance in conducting an inquiry about the surrounding environment.

In the experimental aspect, the students' skill score in conducting experiments for the learning class using modules with cooperative learning STAD is $12.43 \%$ higher than the class using the module without cooperative learning STAD. Experimentation is an attempt to test an object through practical investigation. Some activities using the mind include into the skill of the process of conducting an inquiry. The use of STAD cooperative learning according to [8] can motivate students in groups to help each other so that the skills of observation, experiment, collecting data also make conclusion on students will grow. This is supported by opinion [6] which states that the students who learn with cooperative learning STAD get the opportunity to help each other, discuss, and argue to increase the knowledge.

The increase of average score of science process skill in general can be caused by STAD cooperative learning characteristic. STAD as one of cooperative learning strategy and constructivist-oriented has a syntax that emphasizes learning activities in students or students centered. STAD syntax has component: class presentation, group work, individual development, and evaluation [6] so as to help students to develop thinking skills, problem solving, and intellectual skills. STAD's cooperative learning has a better effect than conventional learning [3], [9], [10].

\section{B. The effect of module implementation as teaching} material combined with Student Team Achievement Division (STAD) cooperative learning toward cognitive achievement student in Life System in Plants for $8^{\text {nd }}$ Grade Junior High School Laboratory State University of Malang.

The results of covariance analysis of this study indicate that science learning that implements module as teaching materials with cooperative learning STAD has a significant effect on the score of cognitive achievement student. Students who are learning with cooperative learning STAD have a higher score average increase than students who learn to use modules without cooperative learning STAD. Increased cognitive achievement can be seen from the increase in the mean score of pretest and postest. When viewed from the mean score corrected (mean), then students who learn with cooperative learning STAD have a higher score of cognitive achievement compared with students who learn using modules without cooperative learning STAD.

The results of the covariance analysis were reinforced with the results of further tests performed by Least Significant Difference (LSD) test. The LSD test shows that there are significant differences in cognitive achievement between the group with module and cooperative learning STAD compared with group use modules but without the cooperative learning of STAD. When expressed in percent, the score of cognitive achievement in the group (class) that implements the module with cooperative learning STAD has a mean score of $4.2 \%$ higher when compared to the class that implements the module without the cooperative learning STAD. The results of this study are in line with the research of [11] which shows that there is a significant correlation between cooperative learning STAD with the mastery of student concepts. 
Improved score of cognitive achievement students in learning that implements modules with cooperative learning STAD is in line with the results of research [12] This research inform that students who learn to use modules with cooperative learning STAD have higher learning outcomes than students who learn to use the module individually. This is also related to [13] opinion that cooperative learning STAD has the advantage in increasing the cooperation in the group and in determining the success of the group depending on individual success, so that each group member can not depend on other group members. Cooperative learning STAD type emphasizes an activity and interaction among students to help each other and motivate in mastering the subject matter so that the cooperation that occurs will involve all members of the group. The active involvement of students is what is believed to enhance the mastery of the concepts embodied with the increased cognitive learning outcomes.

The results of this study indicate that the need for modules delivered through STAD cooperative learning to improve the quality of science learning process based on the ability of students who varied. Students learn in groups consisting of members of different groups of ethnicity and gender so that the quality of student learning can develop with the mutual cooperation and exchange experiences and understanding of students.

\section{CONCLUSION}

The implementation module as teaching materials combined STAD cooperative learning have a significant effect on science process skills and with student's achievement. Scores average of science process skills show $10.41 \%$ higher learning in the classroom using modules with STAD cooperative learning and cognitive achievement is $4.2 \%$. So in general implementation modul as teaching materials combined STAD cooperative learning can improve science process skills and students cognitive achievement.

\section{REFERENCES}

[1] Direktorat Tenaga Kependidikan Ditjen PMTK, "Penulisan Modul.," Jakarta, 2008.

[2] Depdiknas, "Panduan Penyelenggaraan Pembelajaran Tuntas (Mastery-Learning), Direktorat Jenderal Manajemen Pendidikan Dasar dan Menengah," Jakarta, 2008.

[3] S. Armstrong and J. Palmer, "Students Team Achievement Division (STAD) in Twelfth Grade Classroom: Effect on Students Achievement and Attitude,” J. Soc. Stud. Res., vol. 22, no. 1, p. 3, 1998.

[4] A. Arikunto and S. Suharsimi, Dasar-dasar Evaluasi Pendidikan. Jakarta: Bumi Aksara, 2012.

[5] M. Muhfahroyin, "Pengaruh Strategi Pembelajaran Integrasi STAD dan TPS dan Kemampuan Akademik Terhadap Hasil Belajar Kognitif Biologi, Kemampuan Berpikir Kritis, dan Keterampilan Proses Siswa SMA di Kota Metro," Universitas Negeri Malang, 2009.

[6] R. E. Slavin, Cooperative Learning: Teori, Riset dan Praktik. Bandung: Nusa Media, 2005.

[7] J. Abruscato, Teaching Children Science: A Discovery Approach New Jersey: Pearson Education Company, 2000.

[8] A. Prayitno, "Penerapan Pembelajaran Kooperatif Model STAD Terhadap Kualitas Belajar Matematika Siswa SMP," Likhitapradnya, vol. 2 , no. 1,2008

[9] H. M. S. Basoeki, "Pengaruh Pemberian Tugas Autentik Klasikal dan Non-Klasikal dalam Strategi Kooperatif STAD dan GI terhadap Pencapaian Kompetensi Biologi Peserta Didik Kelas XI SMAN di Kota Malang yang Berkemampuan Akademik Berbeda," Malang State University, 2007.

[10] I. Ismail, "Pengaruh Pembelajaran Kooperatif Model STAD dan STM terhadap Hasil Belajar Biologi SMA Negeri 1 Samudra Kabupaten Aceh Utara," Universitas Negeri Malang, 2005.

[11] M. Hamzah and S. Aminah, "Model Pembelajaran Kooperatif STAD dan pengaruhnya terhadap Penguasaan konsep Matematika Siswa kelas VIII di SMPN 1 Ciwaringin Kabupaten Cirebon," Eduma, vol. 1 , no. 1, pp. 85-94, 2009.

[12] D. K. Gitau, "Effect of Cooperative Learning Module on Students Achievement and Atti-tudes Towards Classification of Organisms in Biology in Selected Secondary Schools in Nakuru District, Kenya," Egerton University, 2007.

[13] F. R. Utami, "Penerapan Model Pembelajaran Kooperatif Tipe STAD (Student-Teams-Achievement-Divisions) Untuk Meningkatkan Prestasi Belajar dan Kerjasama Siswa.," http://repository.upi.edu, 2012. 